\title{
Seed bank and growth comparisons of native (Virgilia divaricata) and invasive alien (Acacia mearnsii and $A$. melanoxylon) plants: implications for conservation
}

\author{
Stefan A Goets ${ }^{1,2}$, Tineke Kraaij ${ }^{\text {Corresp., }}{ }^{1}$, Keith M Little ${ }^{1}$ \\ ${ }^{1}$ School of Natural Resource Management, Nelson Mandela University, George, South Africa \\ 2 South African Environmental Observation Network, Kimberley, South Africa \\ Corresponding Author: Tineke Kraaij \\ Email address: tineke.kraaij@mandela.ac.za
}

Background. Invasive alien plants with long-lived dormant seed banks and fast growth rates are difficult to manage. Acacia mearnsii and Acacia melanoxylon are two such invaders in the southern Cape of South Africa which occasionally co-occur with a native, ecologically analogous species, Virgilia divaricata. We compared the performance of these three species to determine potential for the native species to be used in management of the invasives.

Methods. We compared the study species in terms of (i) soil seed bank densities, their vertical distribution, and the viability of seeds underneath the canopies of mature trees; (ii) seedling growth from planted seeds over a period of three months; and (iii) growth rates of saplings over a period of 10 months in stands that have naturally regenerated in the field (these stands were dominated by $A$. mearnsii) and where saplings have been exposed to varying levels of competition from surrounding saplings.

Results. Seed bank densities differed significantly among species but not among soil depth classes. Acacia mearnsii had the highest seed bank densities (mean of 7596 seeds $\mathrm{m}^{-2}$ ), followed by $V$. divaricata (938 seeds $\mathrm{m}^{-2}$ ) and $A$. melanoxylon $\left(274\right.$ seeds $\mathrm{m}^{-2}$ ). Seed viability was high $(87-91 \%)$ in all three study species and did not differ significantly among species or soil depth classes. As seedlings, $V$. divaricata significantly outgrew A. mearnsii in terms of height, root and shoot dry mass, and root:shoot ratio. Relative growth (the relationship between growth in height and initial height) was negative in the seedlings of both species. Trends during the sapling stage were opposite to those during the seedling stage; $A$. mearnsii (but not A. melanoxylon) saplings significantly outgrew $V$. divaricata saplings in height, while relative growth rates were positive in all species. Sapling growth of all species was furthermore uninfluenced by the collective biomass of surrounding competitors.

Discussion. Our findings suggest that amongst the measures considered, $A$. mearnsii's success as an invader is primarily attributable to its large seed banks, and secondly to its vigorous growth in height as saplings. However, the superior growth performance of $V$.divaricata seedlings and no apparent negative effect of competition from the acacias on sapling growth show promise for its use in integrated management of the acacias. 
1 Seed bank and growth comparisons of native (Virgilia divaricata) and invasive alien (Acacia mearnsii and $A$.

2 melanoxylon) plants: implications for conservation

3

4 Stefan A. Goets ${ }^{\mathrm{ab}}$, Tineke Kraaij ${ }^{*}$, Keith M. Little

5

6 a School of Natural Resource Management, Nelson Mandela University, George, South Africa,

7 stefangoets39@gmail.com, Tel. +27 741574212

8 b South African Environmental Observation Network, Kimberley, South Africa

9 c School of Natural Resource Management, Nelson Mandela University, George, South Africa,

10 Tineke.Kraaij@mandela.ac.za, Tel.+27448015018

11 d Nelson Mandela University, School of Natural Resource Management, George, South Africa,

12 Keith.Little@mandela.ac.za, Tel. +27 448015028

13

$14 *$ Corresponding author

15

16 


\section{Abstract}

18 Background. Invasive alien plants with long-lived dormant seed banks and fast growth rates are difficult to manage.

19 Acacia mearnsii and Acacia melanoxylon are two such invaders in the southern Cape of South

20 Africa which occasionally co-occur with a native, ecologically analogous species, Virgilia divaricata. We compared

21 the performance of these three species to determine potential for the native species to be used in management of the

22 invasives.

23 Methods. We compared the study species in terms of (i) soil seed bank densities, their vertical distribution, and the

24 viability of seeds underneath the canopies of mature trees; (ii) seedling growth from planted seeds over a period of

25 three months; and (iii) growth rates of saplings over a period of 10 months in stands that have naturally regenerated

26 in the field (these stands were dominated by A. mearnsii) and where saplings have been exposed to varying levels of

27 competition from surrounding saplings.

28 Results. Seed bank densities differed significantly among species but not among soil depth classes. Acacia mearnsii

29 had the highest seed bank densities (mean of $7596 \mathrm{seeds}^{-2}$ ), followed by $V$. divaricata $\left(938 \mathrm{seeds}^{-2}\right.$ ) and $A$.

30 melanoxylon $\left(274\right.$ seeds $\left.\mathrm{m}^{-2}\right)$. Seed viability was high $(87-91 \%)$ in all three study species and did not differ

31 significantly among species or soil depth classes. As seedlings, $V$. divaricata significantly outgrew A. mearnsii in

32 terms of height, root and shoot dry mass, and root:shoot ratio. Relative growth (the relationship between growth in

33 height and initial height) was negative in the seedlings of both species. Trends during the sapling stage were

34 opposite to those during the seedling stage; A. mearnsii (but not A. melanoxylon) saplings significantly outgrew $V$.

35 divaricata saplings in height, while relative growth rates were positive in all species. Sapling growth of all species

36 was furthermore uninfluenced by the collective biomass of surrounding competitors.

37 Discussion. Our findings suggest that amongst the measures considered, A. mearnsii's success as an invader is primarily attributable to its large seed banks, and secondly to its vigorous growth in height as saplings. However, the superior growth performance of $V$. divaricata seedlings and no apparent negative effect of competition from the acacias on sapling growth show promise for its use in integrated management of the acacias. 


\section{1. Introduction}

43 Competitive performance is an important factor for determining the success or failure of plant invasions and

44 accordingly native-invasive plant competition has been studied extensively (Daehler 2003; Gioria and Osborne

45 2014; Levine et al. 2004; Theoharides and Dukes 2007; Vilà and Weiner 2004). Review studies suggested that the

46 performance of native plants may be equal or superior to that of invasive alien plants (IAPs) under certain conditions

47 (Daehler 2003; Funk et al. 2008), but emphasized the importance of using comparable plant life forms in pair-wise

48 competition experiments (Gioria and Osborne 2014). Native species that show superior performance could

49 potentially aid in the management of invasive species (Vilà and Weiner 2004). Accordingly, habitat management

50 (also termed 'cultural control'), often used in agriculture or forestry (Leihner 2002), involves the alteration of a

51 habitat to favour the target species over that of unwanted species (such as IAPs) and includes the use of native

52 species to increase the amount of competition experienced by the unwanted species (Wittenberg and Cock 2001).

53 Using habitat management as part of an integrated pest management strategy may require high initial investment,

54 but tends to require fewer follow up treatments and rehabilitation may be particularly successful when used in

55 conjunction with other control methods such as biological agents (Hatcher and Melander 2003).

56

57 Seed ecology, and specifically seed bank density and longevity, are important determinants of plant competitive

58 performance (Richardson and Kluge 2008). Seed dormancy allows a species to build up propagule pressure over an

59 extended period of time, increasing its likelihood of survival (Porsild et al. 1967). Invasive plant species with

60 dormant seed banks are particularly difficult to manage since, even after the adult plants are removed, they can

61 recruit en masse if germination requirements are met (Goets et al. 2017; Marchante et al. 2010; Richardson and

62 Kluge 2008). Divergent germination requirements and timing may also influence competitive interactions among

63 species (Finch-Savage and Leubner-Metzger 2006; Gioria \& Osborne 2014; Parker 1989). Inherent growth rate is

64 another important determinant of plant success, whereby rapid initial growth is associated with superior resource

65 acquisition rates, thus enabling exclusion of other, less competitive, species (Craine 2009). The effect of competition

66 may be a reduction in the fitness (i.e. biomass production, flower production, seed production) of one or both of the

67 species (te Beest et al. 2013; Vaugh and Young 2015). Fast growth rates are typically observed in pioneer species,

68 and often account for invasive species being problematic. However, the performance of a native species with similar

69 ecological traits may compare favourably with that of an invasive species in the same environment (Daehler 2003;

70 McDowell and Moll 1981).

71

72 Intact native vegetation is known to present barriers to invasion (Duncan 2011). By the same token, disturbances

73 which reduce or remove competition from native vegetation facilitate invasion by alien plants (Hobbs and Huenneke

74 1992). This suggests that native plant species may potentially be useful in the management of invasive species.

75 Although several studies have compared competitive performance (in terms of seed banks, growth rates and other

76 aspects) between native and alien species pairs (see reviews by Daehler 2003; Funk et al. 2008; Vilà and Weiner

77 2004), few of these have applied their findings to develop invasive plant management strategies that make use of

78 native plant species. However, restoration studies commonly consider the value of native plants, including their soil- 
79

80

81

82

83

84

85

86

87

88

89

90

91

92

93

94

95

96

97

98

99

100

101

102

103

104

105

106

107

108

109

110

111

112

113

114

stored seed banks, to suppress invasives after clearing operations (Bakker and Wilson 2004; Taylor and McDaniel 2004; Tererai et al. 2015). Biological control, although it seldom involves plant-on-plant competition, also relies on exploiting negative interactions among biological organisms to suppress invasive alien plants. Biocontrol agents often target seed production of invasive plants, such as seed boring weevils and flower-galling midges (Adair 2004; Impson et al. 2008, 2009). These slow down the accumulation rate of seeds into seed banks, but the remaining seeds must be accounted for in subsequent management activities to prevent re-establishment of an invasive (Tererai et al. 2015; van Wilgen et al. 2016).

Acacia mearnsii De Wild and Acacia melanoxylon R.Br. are two aggressive invaders in the southern Cape of South Africa and occasionally co-occur with a native, ecologically analogous species, Virgilia divaricata Adamson. All three species are fast-growing, nitrogen-fixing trees in the family Fabaceae. Virgilia divaricata and A. mearnsii are small to medium trees living for 20 to 40 years (Coates-Palgrave et al. 2002; Coetsee and Wigley 2013; Phillips 1926; Searle 1997) and A. melanoxylon is a medium to tall tree living in excess of 100 years (Louppe et al. 2008). The two acacias originate from south-east Australia, A. mearnsii being a pioneer in woodland and forest and $A$. melanoxylon an overstory forest species (Praciak et al. 2013; Searle 1997). Under natural conditions, $V$. divaricata typically occurs in dense monospecific stands along forest edges (forest-fynbos ecotone) after fire, acting as a pioneer for indigenous forest re-establishment (Coates Palgrave et al. 2002; Coetsee and Wigley 2013). The acacias are particularly invasive in disturbance-prone habitats such as riparian zones and forest edges (Baard and Kraaij 2014; Greet 2016; Tererai et al. 2015), a niche often occupied by $V$. divaricata. All three species have soil-stored seeds which may remain dormant for up to 50 years (Geldenhuys 1994; Harrington 1972; Seydack 2002). The seeds require scarification in order to germinate, which is provided by the heat of fire (Jeffery et al. 1988; Searle 1997; Louppe et al. 2008; Goets et al. 2017), or ingestion by birds in the case of A. melanoxylon (Richardson and Kluge 2008). Similarities in germination requirements and timing among the three species suggested that germination requirements and timing are unlikely to confer meaningful competitive advantages to one species over the other (Goets et al. 2017). Virgilia divaricata has the largest seed size of the three species ( $\sim 6 \mathrm{~mm}$ long; Phillips 1926), with both acacias being $3-5 \mathrm{~mm}$ long (Luppe et al. 2008; Praciak et al. 2013). The seeds of $V$. divaricata are not known to be dispersed by biotic agents, whereas those of $A$. mearnsii are dispersed over short distances by ants and A. melanoxylon by birds and water (Greet 2016; Praciak et al. 2013). Seeds of all three species do not require light in order to germinate (Goets et al. 2017), however, their seedlings are shade-intolerant (Louppe et al. 2008; Phillips 1926; Searle 1997). The three species can thus co-occur within the distribution range of $V$. divaricata wherever disturbance has taken place and where seeds are present. Disturbances commonly associated with these species are fires and plantation forestry operations (Baard and Kraaij 2014; Kraaij et al. 2011).

12 In this study, we compared aspects of seed ecology and growth performance between two IAP species (A. mearnsii and A. melanoxylon) and a native ecological analogue ( $V$. divaricata). In particular, we asked whether the native species may outperform the invasive species in terms of their (i) seed bank densities and viability, and (ii) growth 
115 rates both as seedlings and competitively as saplings. We aimed to provide a preliminary screening of the potential

116 for using the indigenous species in integrated management of the invasive species.

117

118 2. Materials and methods

119 2.1. Study sites

120 The study area was the southern Cape coast of South Africa between the towns of George $\left(-33.97^{\circ}, 22.75^{\circ}\right)$ and

121 Nature's Valley $\left(-33.97^{\circ}, 23.55^{\circ}\right)$. The climate of the study area is temperate with an average of $800-1078 \mathrm{~mm}$ of

122 year-round rainfall (peaking in April and October) and daily summer and winter temperatures averaging $20^{\circ} \mathrm{C}$ and

$12312^{\circ} \mathrm{C}$, respectively (Tyson and Preston-Whyte 2000). The underlying geology mostly comprises rocks derived from

124 sandstone, quartzite, and shale forms of the Table Mountain Group (Schafer 1992). All the study sites were situated

125 on the coastal plateau, with mostly colluvial and alluvial soils with yellow-brown to grey-brown colours and sandy

126 loam to silty loam textures (Schafer 1992). The major soil groups of the area are duplex (Estcourt and Klapmuts),

127 hydromorphic (Longlands and Katspruit), and podzols (Lamotte and Witfontein) (Soil Classification Working

128 Group 1991). The vegetation of the area comprises fire-sensitive Southern Afrotemperate forest (Mucina and

129 Geldenhuys 2006) and fire-prone fynbos shrubland (Rebelo et al. 2006). Due to the history of disturbance associated

130 with extensive commercial plantations in the area (Kraaij et al. 2011), high densities of A. mearnsii and to a lesser

131 extent $A$. melanoxylon occur among indigenous fynbos and forest vegetation (Baard \& Kraaij 2014). These invaders

132 are known to alter natural disturbance regimes such as fires, floods, and forest gap formation, which may further

133 promote their proliferation (Kraaij et al. 2013a; Midgley et al. 1990; Russell and Kraaij 2008).

134

135 2.2. Seed banks

136 Seed banks were sampled from underneath canopies of 30 mature trees (10 trees per species) dispersed within the

137 study area (Supplemental S1). Approval was obtained from South African National Parks and MTO Forestry to

138 conduct field studies on land under their jurisdiction. Trees were selected based on criteria regarding stem diameter

$139\left(20-50 \mathrm{~cm}\right.$ at $50 \mathrm{~cm}$ above ground level), slope $\left(<30^{\circ}\right)$, canopy overlap with conspecifics $(<30 \%)$, and habitat type.

140 The study species characteristically occur in four habitat types, namely Southern Afrotemperate forest, fynbos

141 shrubland, forest-fynbos ecotone, and severely disturbed or transformed land (Baard and Kraaij 2014; Coetsee and

142 Wigley 2013). We aimed for comparable representation of habitat types among the study species but did not achieve

143 a perfectly balanced sampling design in terms of this factor (Supplemental S1). For each sampled tree, soil core

144 samples were taken at predetermined sampling locations (at 45 and $90 \mathrm{~cm}$ from the stem) along four radiating

145 transect lines. These four lines were positioned at $90^{\circ}$ intervals, starting at $45^{\circ}$ with $0^{\circ}$ directed upslope. This was to

146 account for potential seed drift down slopes, although seed density did not differ significantly up-slope vs. down-

147 slope of stems (paired t-test $\mathrm{t}_{(29)}=1.79, p=0.084$ ). A core sampler with a diameter of $4.5 \mathrm{~cm}$ and $20 \mathrm{~cm}$ depth was

148 used to take samples. At each sampling location, six litter samples were collected from an area equivalent to the

149 cross-section of the corer, followed by six cores from the surface to $5 \mathrm{~cm}$ ('shallow') and two cores from $5-15 \mathrm{~cm}$

150 ('deep'). Our depth classes followed those of Auld and Denham (2006) where $0-5 \mathrm{~cm}$ represented 'effective

151 germination depths' and the zone where fire may destroy seeds (Pieterse and Boucher 1997; Pieterse and Cairns 
152 1987), whereas germination is possible but rare from depths of $15 \mathrm{~cm}$ (Richardson \& Kluge 2008). Seeds were

153

154

155

156

157

158

159

160

161

162

163

164

165

166

167

168

169

170

171

172

173

174

175

176

177

178

179

180

181

182

183

184

185

186

187

188 extracted from litter and soil samples by sieving out fine material and sorting the remaining material by hand, and thereafter counted. Seed bank density data comprised of seed counts for each soil depth class, and combined for the eight sample plots per tree, resulting in ten replicates per species $\mathrm{x}$ depth class combination. The measure of interest was number of seeds per unit of ground surface area for each of the depth layers as that translates to potential density of recruits which is the aspect of interest in IAP management. This measure also enabled comparison of observed seed bank densities with those reported in the literature.

A tetrazolium-chloride stain test (Porter et al. 1947) was used to determine the proportional viability of seeds from the different species and depth classes. Seeds were cut longitudinally, soaked overnight in a $2 \% 2,3,5$-triphenyltetrazolium chloride solution, and visibly stained seeds enumerated. Ten to fifty seeds (depending on availability from samples) were tested per habitat type per species $\mathrm{x}$ depth class combination, aiming for a total of 100 seeds per species $\mathrm{x}$ depth class combination. In some habitat types, no seeds were obtained in particular species x depth classes, which reduced the number of samples for statistical analysis. Seed viability was expressed as a proportion of viable seeds from the total number of seeds tested per replicate of species $\mathrm{x}$ depth class combination.

\subsection{Seedling growth}

Seeds of $V$. divaricata and $A$. mearnsii (1 500 seeds species $^{-1}$ ) were subjected to a smoke and heat treatment to facilitate germination (Goets et al. 2017), after which the seeds were planted at the beginning of the cold season (June 2014) within an enclosed (to exclude large herbivores) plot on the George Campus of Nelson Mandela University $\left(-33.963833^{\circ}, 22.533333^{\circ}\right)$. Note that the seedling growth study was part of a pilot study, and $A$. melanoxylon had not been considered as a study species at that time. The seeds were planted $1 \mathrm{~cm}$ deep, with the two species arranged randomly and spaced $5 \mathrm{~cm}$ apart for seedlings so as to be unaffected by competition (Midgley et al. 1989). The plot received full sun until late afternoon, as would occur following fire. Above-ground heights of germinants ('seedlings') were measured one $\left(T_{1}\right)$ and three $\left(T_{2}\right)$ months after planting. Seedlings were harvested after the second measurement, and dried to a constant mass in paper bags at $60^{\circ} \mathrm{C}$ for 48 hours. Above and belowground parts (hereafter referred to as 'shoots' and 'roots', respectively) were weighed separately to determine their respective dry masses.

\subsection{Sapling growth}

Circular study plots ( $2 \mathrm{~m}$ radius) were located where at least one individual of $V$. divaricata (considered as reference species) occurred interspersed within stands of co-occurring A. mearnsii and A. melanoxylon and little other vegetation (Figure 1). Eighteen plots were situated at locations $\left(-33.883133^{\circ}, 22.877583^{\circ}\right.$; and $-33.88635^{\circ}$, $23.011617^{\circ}$ ) within the Garden Route National Park where pine plantations were clear-felled three to five years prior to the study, and where saplings subsequently attained sizes of $0.2-8.0 \mathrm{~cm}$ groundline diameter (GLD; stem diameter at $8 \mathrm{~cm}$ above ground level). Saplings of such sizes are ideal for growth studies in displaying rapid (measurable) growth over a short period (Kozlowski 1971). Acacia mearnsii considerably outnumbered the other 
189 two species in all the chosen study plots as we were unable to find sites containing more equitable numbers of

190

191

192

193

194

195

196

197

198

199

200

201

202

203

204

205

206

207

208

209

210

211

212

213

214

215

216

217

218

219

220

221

222

223

224

225

saplings of the three species. Saplings of all three study species, with heights greater than $50 \mathrm{~cm}$, were marked and numbered. The first measurements $\left(T_{1}\right)$ were taken in August - September 2015, and the second ( $\left.T_{2}\right)$ in June 2016.

Measurements included GLD $(\mathrm{cm})$, height $(\mathrm{cm})$, and distance from plot centroid $(\mathrm{cm})$, with a total of 1252 saplings (34 of $V$. divaricata; 1138 of $A$. mearnsii; 80 of $A$. melanoxylon) surveyed. For all marked saplings in the study plots, absolute growth increment $\left(\mathrm{T}_{2}-\mathrm{T}_{1}\right)$ was calculated for height, GLD, and biomass index 'BI' (calculated as GLD squared multiplied by height; Eccles et al. 1997).

To assess competitive performance of individual saplings (of the three study species) in relation to the competition collectively exerted by nearby saplings, a subset of marked saplings was first identified as focal saplings. These focal saplings were all the saplings ( 21 for $V$. divaricata; 331 for A. mearnsii; 33 for A. melanoxylon) that occurred within the central one meter radius plot of the (two meter radius) study plot (Figure 1). The performance of each focal sapling was assessed in relation to the collective competition exerted by the remainder of saplings within the two meter radius plot. Plot competition was expressed as the total BI of all saplings (excluding the focal sapling), by summing the average BI of each sapling between $\mathrm{T}_{1}$ and $\mathrm{T}_{2}$ (a measure of saplings' average biomass during the study period). Relative growth rate in $\mathrm{BI}\left(\frac{T_{2}-T_{1}}{T_{1}}\right)$ was used as the measure of growth in focal saplings, since the relationships between BI increment and initial BI did not differ among species (investigated previously).

2.5. Statistical analyses

2.5.1. Seed bank

To compare seed bank densities among soil depth classes, we multiplied the number of seeds extracted from the deep layer (where two cores were sampled per tree as opposed to six in each of the shallow and litter layers) by a factor of three. Conversion to seeds $\mathrm{m}^{-2}$ was done per sample area by multiplying the seed count with a factor of $104.79\left(10000 \mathrm{~cm}^{2}\right.$ divided by $95.42 \mathrm{~cm}^{2}$, which is the surface area of six cores or one sample area per tree), and then averaged per tree. Due to non-normality the data were $\log (\mathrm{x}+1)$ transformed (Barlett 1947). We used mixedmodel analysis of variance (ANOVA) (Littell 2002) to assess the effects on seed bank density of species and depth class (as fixed effects), habitat type (as random effect), and second-order interactions among these (as fixed effects).

The effects of species and depth class on seed viability were tested (representation across habitat types was too poor to enable inclusion of this factor). The viability expressed as proportions did not conform to assumptions of normality and homogeneity of variance and were subjected to a rank transformation. The ranked and unranked data were tested using a factorial ANOVA, yielding comparable results. Test results from the unranked data were regarded as valid, as the assumptions for ANOVA were reasonably satisfied (Montgomery 2013).

\subsubsection{Seedling growth}

Root and shoot dry masses, and calculated root:shoot ratios did not conform to assumptions of normality and homogeneity of variance, thus between species comparisons were made using Mann-Whitney U tests (using the Zscore; Privitera 2017). Absolute height increment was calculated $\left(\mathrm{T}_{2}-\mathrm{T}_{1}\right)$ and its relationship with initial height (at 
$226 \mathrm{~T}_{1}$ ) explored - this relationship constitutes 'relative growth rate'. To determine whether relative growth in $A$.

227 mearnsii differed from that in $V$. divaricata we used a general linear model (GLM) with height increment as the

228 dependent variable and initial seedling height and species (incorporated as dummy variable with $V$. divaricata as

229 reference species) as explanatory variables.

230

231

\subsubsection{Sapling growth}

232 GLMs were used to explore whether relative growth rates in terms of height, GLD, and BI differed between the 233 acacias and $V$. divaricata, with initial size (at $\mathrm{T}_{1}$ ) and species (as dummy variables with $V$. divaricata as reference

234 species) as explanatory variables. To explore how relative growth rate in BI of focal saplings was affected by the

235 extent of competition ( plot biomass) and whether this differed among species, a GLM was conducted on the relative growth rate in BI of focal saplings as the dependent variable, and plot biomass and species (as dummy variables with $V$. divaricata as reference species) as explanatory variables. As the primary inquiry in this part of the study was in terms of differences in competitive growth among species, GLM slope coefficients (as opposed to intercept coefficients) relevant to species comparisons were the focus in interpretations (comprehensive GLM outputs were provided in Supplemental S2). All statistical analyses were carried out using STATISTICA v.13 (Dell

241 Inc. 2015).

242

243

\section{Results}

244 3.1. Seed banks

245 Seed bank densities differed significantly among species and among habitat types but not among soil depth classes

246 (Table 1; Figure 2a\&b). Acacia mearnsii had the highest seed bank densities, followed by $V$. divaricata and $A$.

247 melanoxylon. The average seed bank density in the sampled soil profile, for all three species, was $2936 \mathrm{seeds}^{-2}$,

248 with large variation (from $\sim 100$ to several thousand seeds $\mathrm{m}^{-2}$ ) evident in all three species (Table 2). There was a

249 significant interaction between species and habitat (Table 1) with seed densities being disproportionately high in $A$. 250 mearnsii in disturbed habitat, and in $V$. divaricata in forest-fynbos ecotone and disturbed habitat (Figure $2 a$ ). In 251 terms of reliability of seed banks, $V$. divaricata and A. mearnsii appeared to maintain seed banks more consistently 252 (with $22 \%$ and $20 \%$ of sample plots per depth class yielding no seed, respectively) than A. melanoxylon (63\%). Seed 253 viability was high in all three species (A. mearnsii 91\%, V. divaricata 88\%, and A. melanoxylon 87\%) and did not 254 differ significantly among species $\left(\mathrm{F}_{(2,20)}=0.83 ; p=0.452\right)$ or depth classes $\left(\mathrm{F}_{(2,20)}=3.01 ; p=0.072\right)($ Figure $2 \mathrm{c})$.

$255<<<$ Table $1>>>$

$256<<<$ Table $2>>>$

$257<<<$ Figure $2>>>$

258

259

\subsection{Seedling growth}

260 Root dry mass $(Z=-11.767 ; p<0.001)$, shoot dry mass $(Z=-10.914 ; p<0.001)$, and root:shoot ratio $(Z=-9.625 ; p$ $261<0.001$ ) of harvested seedlings were significantly higher in $V$. divaricata (average root mass $132 \mathrm{mg}$; shoot mass 98 $262 \mathrm{mg}$; root:shoot ratio 1.48) than in A. mearnsii (8 mg; $15 \mathrm{mg} ; 0.63$ ) (Figure 3). Virgilia divaricata displayed a 
263

264

265

266

267

268

269

270

271

272

273

274

275

276

277

278

279

280

\section{4. Discussion}

282 4.1. Seed banks

283 One of the most apparent differences among the study species related to seed bank densities with the average of

284

285

286

287

288

289

290

291

292

293

294

295

296

297

298

significant negative relationship between growth in height and initial height, with the relationship for $A$. mearnsii not differing significantly from $V$. divaricata (Figure 4a\&b; Supplemental S2). Growth rates of seedlings declined during the two to three months following germination. The average height of seedlings at three months was $5.3 \mathrm{~cm}$ and $1.0 \mathrm{~cm}$ for $V$. divaricata and $A$. mearnsii respectively, with maximum heights of $9.8 \mathrm{~cm}$ and $1.5 \mathrm{~cm}$ respectively.

$<<<$ Figure 3>>>

$<<<$ Figure $4>>>$

\subsection{Sapling growth}

Saplings of all three species displayed positive relationships between their growth increment and initial size (in terms of height, GLD, and BI, although not significant in terms of height in $V$. divaricata and GLD in $A$.

melanoxylon; Figure 4). The relationship between initial height and height increment was significantly more positive for $A$. mearnsii than for $V$. divaricata but it did not differ between $V$. divaricata and $A$. melanoxylon (Figure 4c-e; Supplemental S2). The positive relationship between initial GLD and GLD increment was significant for $V$. divaricata and did not differ from that of $A$. mearnsii, while being significantly more positive than that of $A$. melanoxylon (Figure 4f-h). The positive relationship between initial BI and BI increment was significant for $V$. divaricata and did not differ from the two acacias (Figure 4i-k). The extent of competition (summed competitor BI) had no effect on the growth (relative increase in BI) of focal saplings of any of the study species (Supplemental S2). A. mearnsii being almost one order of magnitude larger than $V$. divaricata, while seed densities in A. melanoxylon were the smallest. Our estimates of seed bank densities varied widely within species, with ranges observed in $V$. divaricata and A. mearnsii being largely consistent with previous investigations (Table 2), but substantially lower in A. melanoxylon than recorded by Donald (1959). Generally seed banks are highly variable in space and time and are affected by various factors, inter alia climate, habitat type, geomorphology, population demographics, plant density, dispersal strategy, and seed predation (Parker 1989). Seed densities of A. mearnsii that have been disproportionately high in disturbed habitat likely reflect competitive growth and prolific seed production by this disturbance-driven, shade-intolerant species (Geldenhuys 2004) in relatively open, disturbed environments. Seed densities of $V$. divaricata that have been comparatively high in forest-fynbos ecotone and disturbed habitat are in line with this species' ecological role as forest precursor in disturbed or burnt forest margins (Coetsee and Wigley 2013). Low seed densities observed in A. melanoxylon across habitat types may partly result from bird dispersal (Richardson and Kluge 2008) and prolonged (since 1986) exposure to a highly effective seed-boring weevil (Melanterius acacia Lea) as biocontrol agent (Dennill et al. 1999; Impson et al. 2009). In contrast, biocontrol on A. mearnsii in the form of a seed-boring weevil (Melanterius maculatus Lea) is more recent (introduced in 1993) and only moderately effective, while the more effective flower-galling midge (Dasineura rubiformis Kolesik; introduced in 2001) is still localised 
299

300

301

302

303

304

305

306

307

308

309

310

311

312

313

314

315

316

317

318

319

320

321

322

323

324

325

326

327

328

329

330

331

332

333

334

335

(Adair 2004; Impson et al. 2008, 2009). Relative to other invasive acacias in South Africa (Milton and Hall, 1981;

Richardson and Kluge, 2008), the seed bank densities of $A$. mearnsii can be considered moderate to high (similar to Acacia longifolia (Andr.) Willd. and Acacia saligna (Labill.) H.L.Wendl.), those of V. divaricata low to moderate (similar to Acacia cyclops A.Cunn. ex G.Don), and those of A. melanoxylon the lowest recorded for invasive acacias.

Seed bank densities within species were largely comparable among soil depth classes, with all species displaying a non-significant trend of having fewer seeds in the litter layer than in the shallow and deep layers (most pronounced in A. melanoxylon). This trend may in part be due to high levels of seed predation and lateral drift in the litter layer (Holmes 1990; Richardson and Kluge 2008). Seed densities in the shallow and deep soil layers were comparable in our study, although Richardson and Kluge (2008) found that seed bank densities in Australian acacias rapidly decline below a depth of $8 \mathrm{~cm}$. The presence of substantial seed densities in deeper soil layers has important management implications (see below).

Seed viability was comparably high (87-91\%) in all three study species, and corresponded well with ranges reported in the literature (Table 2) and viability observed for A. cyclops, A. longifolia, and A. saligna (Milton and Hall, 1981; Richardson and Kluge, 2008). Viability did not differ significantly among layers in the soil profile, as expected of species with long-lived dormant seeds (Holmes 1989). Acacia melanoxylon appeared to have the most variability in viability among layers. In characterising the study species' seed ecology, our findings confirmed that $A$. mearnsii exhibited 'Type A' traits (O’Dowd \& Gill 1986; Richardson \& Kluge 2008), in that large seed banks (Table 2) signified rapid accumulation rates, while equally viable seeds in deep and shallow soil layers (Figure 2b) signified persistent water-impermeability of seed coats; and that A. melanoxylon exhibited 'Type B' traits, in that small seed banks signified gradual accumulation of seeds, while lower seed viability in deep than in shallow soil layers signified more permeable seed coats. We consider $V$. divaricata to have 'Type A' traits given its relatively large seed banks, comparable seed viability in different soil layers ( high dormancy), and occurrence in fire prone habitat. An opportunistic field survey (Supplemental S3) showed that comparably small proportions of the soil-stored seed banks of $V$. divaricata (19\%) and A. mearnsii (14\%) germinated after a fire (Wilcoxon matched pairs test $\mathrm{Z}=0.511$, $\mathrm{p}=0.609$ ). Fire-stimulated germination of only a small proportion of the seed bank due to high physical dormancy provides further evidence for 'Type A' seed ecology in both species.

\subsection{Growth performance}

The second apparent difference among the study species was that $V$. divaricata significantly outperformed $A$. mearnsii in the seedling stage in terms of root and shoot dry mass (Figure 3) and growth in height (Figure 4). The superior performance of $V$. divaricata seedlings may relate to its larger seeds providing the seedlings with larger cotyledons (larger initial photosynthetic area) and more rapid hypocotyl extension due to increased seed reserves (Leishman et al. 2000). Seedlings of the closely related $V$. oroboides (originally thought to be the same species as $V$. divaricata; Coates Palgrave et al. 2002) similarly outperformed those of two other alien species, A. longifolia and 
336

337

338

339

340

341

342

343

344

345

346

347

348

349

350

351

352

353

354

355

356

357

358

359

360

361

362

363

364

365

366

367

368

369

370

371

372

Albizia lophanta (McDowell \& Moll 1981). Virgilia divaricata seedlings furthermore invested more resources in root development than in aboveground development relative to $A$. mearnsii seedlings.

Our study of relative growth rates revealed some important differences between $V$. divaricata and A. mearnsii suggesting that they utilise divergent growth strategies during the seedling and sapling stages (Kozlowski 1971). However, A. mearnsii showed significantly more positive growth in height relative to initial sapling height than $V$. divaricata (and A. melanoxylon), while relative growth rates were similar among species in terms of GLD and BI. Overall, $V$. divaricata with its larger seeds invested in and outperformed A. mearnsii in terms of growth in height during the seedling stage, but the opposite occurred during the sapling stage. To establish which of these species would be the best performer overall would require long-term assessments of their growth. However, $A$. mearnsii was found to be more efficient at $\mathrm{N}$ resorption and better adapted to low-nutrient environments (characteristic of the study area) than $V$. divaricata (Van der Colff et al. 2017).

A third, albeit unexpected finding, was that competitor biomass had no recorded negative effect on the relative growth in $\mathrm{BI}$ in focal saplings of any species. Considering that the majority of competitors (and thus competitor biomass) in this study consisted of $A$. mearnsii, this result suggested that $A$. mearnsii does not have an apparent negative effect on growth of $V$. divaricata saplings, even at high densities of the former. This suggests the absence of allelopathic effects of $A$. mearnsii on $V$. divaricata during the sapling stage, congruent with the finding that $A$. longifolia did not inhibit $V$. oroboides germination although the opposite occurred (McDowell \& Moll 1981). Acacia melanoxylon rarely had numerous or substantially sized saplings occurring in plots, making interpretation involving this species less meaningful.

\subsection{Conservation implications}

Overall, our findings suggest that amongst the measures considered, the success of $A$. mearnsii as an invader is primarily attributable to its large seed banks, and to a lesser extent its vigorous growth in height as saplings.

However, the superior growth performance of $V$. divaricata seedlings and no apparent negative effect of competition from the acacias on sapling growth show promise for its use in integrated management of the acacias. For small, localised infestations, the clearing of acacias can be followed by seeding with pre-treated (chipped or hot water exposed; Goets et al. 2017) seeds of $V$. divaricata, particularly in habitats such as forest margins where $V$. divaricata would occur naturally. Our results suggest that $V$. divaricata saplings are likely to grow well even if interspersed with dense acacias. If $V$. divaricata is afforded a period in which dense stands could establish, this would also promote forest re-establishment, while subsequent germination and growth of the acacias would be suppressed. Such an approach in invaded fynbos shrublands may however in the long-term result in replacement of remaining fynbos by forest species (Coetsee and Wigley 2013). The leaf litter of $V$. divaricata may furthermore play a role in the prevention of Acacia germination, as A. longifolia germination was found to be reduced under $V$. oroboides litter but not vice versa (McDowell \& Moll 1981). The similarities observed between the three species in terms of seed viability and responses to germination stimuli (including timing of germination; Goets et al. 2017) would mean that 
373 management operations (such as fire) that would benefit $V$. divaricata recruitment would benefit the acacias equally

374 and thus reduce its efficacy. In addition to the high densities of $A$. mearnsii seeds occurring within the shallow soil

375 layer (i.e. at effective germination depth; Pieterse and Boucher 1997), the presence of equally high densities of seeds

376 in deeper soil may render attempts at depleting the soil seed bank even more challenging. At a local scale, repeated

377 fires may be used to deplete the shallower soil seed bank (Auld and Denham 2006; Pieterse and Boucher 1997;

378 Pieterse \& Cairns 1988), but the rapid progression of $A$. mearnsii seedlings to reproductive maturity ( 2 years;

379 Praciak et al. 2013) may result in additional seed production before an adequate fuel load exists. Alternatively, soil

380 solarisation (Cohen et al. 2013) may be employed to deplete shallow seed banks, whereas soil inversion (Holmes

381 and Moll 1990) would be required to deplete deeper seed banks. At larger scales, management should rather attempt

382 to prevent the germination of Acacia seeds by limiting disturbance events that remove aboveground vegetation,

383 including fire. In fire-prone fynbos, managers should aim for fire return intervals toward the upper end of the

384 ecologically acceptable range (Kraaij et al. 2013b). Given the smaller seed banks, but bird dispersed seeds of

385 A. melanoxylon, new recruitment subsequent to clearing operations needs to be monitored over larger areas than in

386 the case of $A$. mearnsii. To further decrease Acacia success, biological control, including seed-boring weevils,

387 flower-galling midges, and a rust fungus (Impson et al. 2008, 2009; McTaggart et al. 2015) should be widely

388 distributed.

389

\section{5. Conclusions}

391 Seed bank densities were significantly higher in $A$. mearnsii than in $V$. divaricata and A. melanoxylon (in decreasing

392 order of abundance), while seed viability was comparatively high in all three species. Seed densities and viability

393 did not differ significantly among soil depth layers, suggesting strong seed dormancy in all three species. Virgilia

394 divaricata outgrew $A$. mearnsii in the seedling stage, but during the sapling stage $A$. mearnsii outgrew $V$. divaricata

395 in height. Sapling growth in all species appeared uninfluenced by the extent of competition posed by neighbouring saplings. These findings support the notion that invasive plants do not necessarily outperform native counterparts in the invaded environment when exposed to similar conditions (cf. Daehler 2003; Funk et al. 2008; Gioria and Osborne 2014) and that $V$. divaricata in some respects (outlined above) shows potential for use in integrated management of the acacias. We recommend that competition among the study species be further investigated in

400 more controlled and longer-term approaches, for instance planting pre-germinated seeds at particular spacing and densities to allow for investigation of the effect of species dominance on competitive interactions across all life

402 stages.

403

404

\section{Acknowledgements}

405 We thank South African National Parks and Mountain to Ocean Forestry for permitting sample collection and the 406 establishment of study plots on land under their jurisdiction. We thank Jeanette Pauw for advice with statistical 407 analyses, Benjamin Wigley and Jaco Barendse for their involvement in planning the seedling study, and the 408 following people for assistance with data collection: Marius Strydom, Aletta Botha, Zanri Schoeman, Tiaan 
409 Strydom, Gert Botha, Willem Matthee, Kara Marais, Matthew Barnard, Evidence Siwela, Thembisa Sibhakabhaka, 410 Melda Goets, and Christopher Brooke.

411

412 References

413 Adair RJ (2004) Seed-reducing Cecidomyiidae as potential biological control agents for invasive Australian wattles in South Africa, particularly Acacia mearnsii and A. cyclops (Ph.D). University of Cape Town, Cape Town.

415 Auld TD, Denham AJ (2006) How much seed remains in the soil after a fire? Plant Ecology 187: $15-24$.

416 Baard JA, Kraaij T (2014) Alien flora of the Garden Route National Park, South Africa. South African Journal of Botany 94(3):51-63. doi:10.1016/j.sajb.2014.05.010

Bakker JD, Wilson SD (2004) Using ecological restoration to constrain biological invasion. Journal of Applied Ecology 41:1058-1064.

421 Coates Palgrave M, Drummond RB, Moll EJ (eds) (2002) Trees of Southern Africa, 3rd edn. Struik Publishers, 422 Cape Town.

423

424

425

426

427

428

429

430

431

432

433

434

435

436

437

438

439

440

441

442

443

444

Coetsee C, Wigley B (2013) Virgilia divaricata may facilitate forest expansion in the afrotemperate forests of the southern Cape, South Africa. Koedoe 55:8 pages.

Cohen O, Riov J, Katan J, Gamliel A, Bar P (2013) Reducing persistent seed banks of invasive plants by soil solarisation: the case of Acacia saligna. Weed Science 56(6):860-865. doi:10.1614/WS-08-073.1

Craine JM (2009) Resource strategies of wild plants. Princeton University Press, New Jersey.

Daehler CC (2003) Performance comparisons of co-occurring native and alien invasive plants: implications for conservation and restoration. Annual Review of Ecology, Evolution, and Systematics 34:183-211. doi:10.1146/annurev.ecolsys.34.011802.132403

Dennill GB, Donnelly D, Stewart K, Impson FAC (1999) Insect agents used for the biological control of Australian Acacia species and Paraserianthes lophantha (Willd.) Nielsen (Fabaceae) in South Africa. African Entomology Memoir 1:45-54.

Donald DGM (1959) Report on Acacia melanoxylon in the Midlands Conservatory. Unpublished report. Department of Forestry, South Africa.

Duncan RP (2011) Propagule pressure, in: Simberloff D, Rejmánek M (eds) Encyclopedia of biological invasions, pp. 561-563, University of California, Berkeley, CA.

Eccles NS, Kritzinger JL, Little KM (1997) Appropriateness of non-destructive measures of young pine tree performance in weeding experiments. Southern African Forestry Journal 178:25-29. doi:10.1080/10295925.1997.9631135

Finch-Savage WE, Leubner-Metzger G (2006) Seed dormancy and the control of germination: Tansley review. New Phytologist 171:501-523.

Funk JL, Cleland EE, Suding KN, Zavaleta ES (2008) Restoration through reassembly: plant traits and invasion resistance. Trends in Ecology \& Evolution 23:695-703. doi:10.1016/j.tree.2008.07.013 
445 Garner RD (2007) Vegetation response to clearing of exotic invasive plants along the Sabie River, South Africa

446

447

448

449

450

451

452

453

454

455

456

457

458

459

460

461

462

463

464

465

466

467

468

469

470

471

472

473

474

475

476

477

478

479

480

481

(MSc). University of Witwatersrand, Johannesburg.

Geldenhuys CJ (1994) Bergwind fires and the location pattern of forest patches in the southern Cape landscape, South Africa. Journal of Biogeography 21:49-62. doi:10.2307/2845603

Geldenhuys CJ (2004) Concepts and process to control invader plants in and around natural evergreen forest in South Africa. Weed Technology 18:1386-1391.

Gioria M, Osborne BA (2014) Resource competition in plant invasions: emerging patterns and research needs. Frontiers in Plant Science 5:Art.\#501. doi:10.3389/fpls.2014.00501

Goets SA, Kraaij T, Little KM (2017) Comparing germination stimuli of two alien invasive species and a native analogue: towards sustainable management of invasives. South African Journal of Botany 112:15-18. doi:10.1016/j.sajb.2017.05.002

Greet J (2016) The potential of soil seed banks of a eucalypt wetland forest to aid restoration. Wetlands Ecology and Management 24(5):565-577.

Harrington JF (1972) Seed storage and longevity, in: Kozalowski TT (ed) Seed biology: insects and seed collection, storage, testing, and certification, Vol. 3. Physiological Ecology. Academic Press Inc, New York.

Hatcher PE, Melander B (2003) Combining physical, cultural and biological methods: prospects for integrated nonchemical weed management strategies. Weed Research 43:303-322. doi:10.1046/j.1365-3180.2003.00352.x

Hobbs RJ, Huenneke LF (1992) Disturbance, diversity and invasion: implications for conservation. Conservation Biology 6:324-337.

Holmes PM (1989) Decay rates for buried Acacia seed populations of different density. South African Journal of Botany 55:299-303. doi:10.1016/S0254-6299(16)31179-6

Holmes PM (1990) Dispersal and predation in alien Acacia. Oecologia 83:288-290. doi:10.1007/BF00317768

Holmes PM, Moll EJ (1990) Effect of depth and duration of burial on alien Acacia saligna and Acacia cyclops seeds. South African Journal of Ecology 1:12-17.

Impson F, Hoffmann J, Kleinjan C (2009) Australian Acacia species (Mimosaceae) in South Africa, in: Muniappan R, Reddy GVP, Raman A (eds) Biological control of tropical weeds using arthropods. Cambridge University Press, New York.

Impson FAC, Kleinjan CA, Hoffmann JH, Post JA (2008) Dasineura rubiformis (Diptera: Cecidomyiidae), a new biological control agent for Acacia mearnsii in South Africa. South African Journal of Science 104:247249.

Jeffery DJ, Holmes PM, Rebelo AG (1988) Effects of dry heat on seed germination in selected indigenous and alien legume species in South Africa. South African Journal of Botany 54:28-34. doi:10.1016/S0254$6299(16) 31358-8$

Kozlowski TT (1971) Growth and Development of Trees, Vol. 1. Academic Press, Inc, New York.

Kraaij T, Cowling RM, van Wilgen BW, Das S (2013a) Historical fire regimes in a poorly-understood, fire-prone ecosystem: eastern coastal fynbos. International Journal of Wildland Fire 22(3):277-287. doi:10.1071/WF11163. 
482

483

484

485

486

487

488

489

490

491

492

493

494

495

496

497

498

499

500

501

502

503

504

505

506

507

508

509

510

511

512

513

514

515

516

517

518

Kraaij T, Cowling RM, van Wilgen BW (2013b) Fire regimes in eastern coastal fynbos: imperatives and thresholds in managing for diversity. Koedoe 55(1):Art. \#1104, 9 pages. http://dx.doi.org/10.4102/koedoe.v55i1.1104

Kraaij T, Cowling RM, van Wilgen BW (2011) Past approaches and future challenges to the management of fire and invasive alien plants in the new Garden Route National Park. South African Journal of Science 107(9/10):Art.\#633, 11 pages, doi:10.4102/sajs.v107i9/10.633.

Leihner D (2002) Agronomy and cropping systems, in: Hillocks RJ, Thresh JM, Bellotti A (eds), Cassava: Biology, Production and Utilization. CABI, Wallingford.

Leishman MR, Wright IJ, Moles AT, Westoby M (2000) The evolutionary ecology of seed size, in: Fenner M (ed), Seeds: the ecology of regeneration in plant communities. CABI, Wallingford

Levine JM, Adler PB, Yelenik SG (2004) A meta-analysis of biotic resistance to exotic plant invasions: biotic resistance to plant invasion. Ecology Letters 7:975-989. doi:10.1111/j.1461-0248.2004.00657.x

Littell RC (2002) Analysis of unbalanced mixed model data: a case study comparison of ANOVA versus REML/GLS. Journal of Agricultural, Biological, and Environmental Statistics 7:472-490.

Louppe D, Oteng-Amoako AA, Brink M, Lemmens RHMJ, Oyen LPA, Cobbinah JR (2008) Plant Resources of Tropical Africa 7 (1). Timbers 1. PROTA foundation, Wageningen.Marchante H, Freitas H, Hoffmann JH (2010) Seed ecology of an invasive alien species, Acacia longifolia (Fabaceae), in Portuguese dune ecosystems. American Journal of Botany 97:1780-1790. doi:10.3732/ajb.1000091

McDowell CR, Moll EJ (1981) Studies of seed germination and seedling competition in Virgilia oroboides (Berg.) Salter, Albizia lophantha (Willd.) Benth. and Acacia longifolia (Andr.) Willd. Journal of South African Botany 47(4):653-685.

McTaggart AR, Doungsa-ard C, Wingfield MJ, Roux J (2015) Uromycladium acaciae, the cause of a sudden, severe disease epidemic on Acacia mearnsii in South Africa. Australasian Plant Pathology 44(6): 637-645. doi:10.1007/s13313-015-0381-4

Midgley J, Seydack A, Reynell D, McKelly D (1990) Fine-grain pattern in Southern Cape plateau forests. Journal of Vegetation Science 1:539-546. doi:10.2307/3235788

Midgley JJ, Hoekstra T, Bartholomew R (1989) The effects of date of planting on field establishment of serotinous Cape Proteaceae. Vegetatio 79:185-192. doi:10.1007/BF00044910Milton SJ, Hall AV (1981) Reproductive biology of Australian Acacias in the south-western Cape province, South Africa. Transactions of the Royal Society of South Africa 44:465-485. doi:10.1080/00359198109520589

Montgomery DC (2013) Design and analysis of experiments 8th edn. Wiley \& Sons, Inc, Hoboken.

Mucina L, Geldenhuys CJ (2006) Afrotemperate, subtropical and azonal forests, in: Mucina L, Rutherford MC (eds), The vegetation of South Africa, Lesotho and Swaziland, Strelitzia 19. South African National Biodiversity Institute, Pretoria.

O’Dowd DJ, Gill AM (1986) Seed dispersal syndromes of Australian Acacia, in: Murray D (ed), Seed dispersal, pp. 87-121. Academic Press, New York.

Parker VT (1989) Patterns and process in the dynamics of seed banks, in: Leck MA, Parker VT, Simpson RL (eds), Ecology of soil seed banks. Academic Press, San Diego. 
519 Phillips JFV (1926) Virgilia capensis Lamk. ("keurboom”): a contribution to its ecology and sylviculture. South

520

521

522

523

524

525

526

527

528

529

530

531

532

533

534

535

536

537

538

539

540

541

542

543

544

545

546

547

548

549

550

551

552

553

554

555 African Journal of Science 23:435-454.

Pieterse PJ (1997) Biological studies on woody leguminous invaders with special reference to Acacia mearnsii, Acacia melanoxylon and Paraserianthes lophantha (Ph.D.). Stellenbosch University, Stellenbosch.

Pieterse PJ, Boucher C (1997) Is burning a standing population of invasive legumes a viable control method? Effects of wildfire on an Acacia mearnsii population. Southern African Forestry Journal 180: 15-21.

Pieterse PJ, Cairns ALP (1987) The effect of fire on an Acacia longifolia seed bank in the south-western Cape. South African Journal of Botany 52(3):233-236. doi:10.1016/S0254-6299(16)31555-1

Pieterse PJ, Cairns ALP (1988) The population dynamics of the weed Acacia longifolia (Fabaceae) in the absence and presence of fire. South African Forestry Journal 145:25-27. doi:10.1080/00382167.1988.9630330

Porsild AE, Harrington CR, Mulligan GA (1967) Lupinus arcturicus Wats. grown from seed of Pleistocene age. Science 158:113-114.

Porter RH, Durrell M, Romm HJ (1947) The use of 2, 3, 5-triphenyl-tetrazoliumchloride as a measure of seed germinability. Plant Physiology 22:149-159.

Praciak A, Pasiecznik N, Sheil D, van Heist M, Sassen M, Correia CS, Dixon C, Fyson G, Rushford K, Teeling, C (eds) (2013) The CABI encyclopedia of forest trees. CABI, Oxfordshire.

Privitera GJ (2017) Statistics for the behavioural sciences. SAGE Publications, California.

Rebelo AG, Boucher C, Helme N, Mucina L, Rutherford MC (2006) Fynbos biome, in: Mucina L, Rutherford MC (eds), The vegetation of South Africa, Lesotho and Swaziland, Strelitzia 19. South African National Biodiversity Institute, Pretoria.

Rees M, Osborne CP, Woodward FI, Hulme SP, Turnbull LA, Taylor SH (2010) Partitioning the components of relative growth rate: how important is plant size variation? The American Naturalist 176:152-161. doi:10.1086/657037

Richardson DM, Kluge RL (2008) Seed banks of invasive Australian Acacia species in South Africa: role in invasiveness and options for management. Perspectives in Plant Ecology, Evolution and Systematics 10:161-177. doi:10.1016/j.ppees.2008.03.001

Russell IA, Kraaij T (2008) Effects of cutting Phragmites australis along an inundation gradient, with implications for managing reed encroachment in a South African estuarine lake system. Wetlands Ecology and Management 16:383-393. doi:10.1007/s11273-007-9075-1

Schafer GN (1992) Classification of forest land in the southern Cape region (M.Sc.). University of Natal, Pietermaritzburg.

Searle SD (1997) Acacia mearnsii De Wild. (Black Wattle) in Australia, in: Brown AG, Ko HC (eds), Black wattle and its utilisation. Rural Industries Research and Development Corporation, Barton.

Seydack AHW (2002) Management options for Australian Blackwood (Acacia melanoxylon) in Southern Cape Forests, South Africa. The Southern African Forestry Journal 196:55-66.

Soil Classification Working Group (1991) Soil classification, a taxonomic system for South Africa, Department of Agricultural Development, Pretoria. 
556 Taylor JP, McDaniel KC (2004) Revegetation strategies after saltcedar (Tamarix species) control in headwater, transitional, and depositional watershed areas. Weed Technology 18:1278-1282.

558 te Beest M, Elschot K, Olff H, Etienne RS (2013) Invasion success in a marginal habitat: an experimental test of 559 competitive ability and drought tolerance in Chromolaena odorata. PLoS One 8:8 pages.

560 doi:10.1371/journal.pone.0068274

561 Tererai F, Gaertner M, Jacobs SM, Richardson DM (2015) Resilience of invaded riparian landscapes: the potential 562 role of soil-stored seed banks. Environmental Management 55:86-99.

563 Theoharides KA, Dukes JS (2007) Plant invasion across space and time: factors affecting nonindigenous species

564 success during four stages of invasion. New Phytologist 176:256-273. doi:10.1111/j.1469-

$565 \quad$ 8137.2007.02207.x

566 Tyson PD, Preston-Whyte RA (2000) The weather and climate of Southern Africa. Oxford University Press, Cape 567 Town.

568 Van der Colff D, Dreyer LL, Valentine A, Roets F (2017) Comparison of nutrient cycling abilities between the

569 invasive Acacia mearnsii and the native Virgilia divaricata trees growing sympatrically in forest margins in

570 South Africa. South African Journal of Botany 111:358-364.

571 van Wilgen BW, Fill JM, Baard J, Cheney C, Forsyth AT, Kraaij T (2016) Historical costs and projected future

572 scenarios for the management of invasive alien plants in protected areas in the Cape Floristic Region.

573 Biological Conservation 200:168-177. doi:10.1016/j.biocon.2016.06.008

574 Vaugh KJ, Young TP (2015) Short-term priority over exotic annuals increases the initial density and longer-term

$575 \quad$ cover of native perennial grasses. Ecological Applications 25:791-799. doi:10.1890/14-0922.1

576 Vilà M, Weiner J (2004) Are invasive plant species better competitors than native plant species? Evidence from

577 pair-wise experiments. Oikos 105:229-238. doi:10.1111/j.0030-1299.2004.12682.x

578 Wittenberg R, Cock MJW (eds) (2001) Invasive alien species: a toolkit of best prevention and management practices. CABI, Wallingford. 


\section{Figure 1 (on next page)}

Schematic of plot layout pertaining to sapling growth assessments.

Hypothetical sampling plot where growth of all saplings (i.e. occurring in the inner and outer circles) with height $>50 \mathrm{~cm}$ of Virgilia divaricata (' $V$ ' and ' $V$ '), Acacia mearnsii (' $R$ ' and ' $r$ ') and $A$. melanoxylon (' $X$ ' and ' $X$ ') were measured. Additionally we assessed the effect of competition exerted by nearby saplings on the growth of focal saplings individually. For this assessment, each focal sapling $(\mathrm{V}, \mathrm{R}$, or $\mathrm{X})$ occurred within the inner one meter radius circular plot (shaded), and each focal sapling's growth increment was related to the summed biomass (expressed as an index, see text) of all the remaining saplings $(V, R, X, V, r$, and $x$ ) within the remainder of the one meter radius (shaded) and two meter radius (unshaded) circular plots combined. 


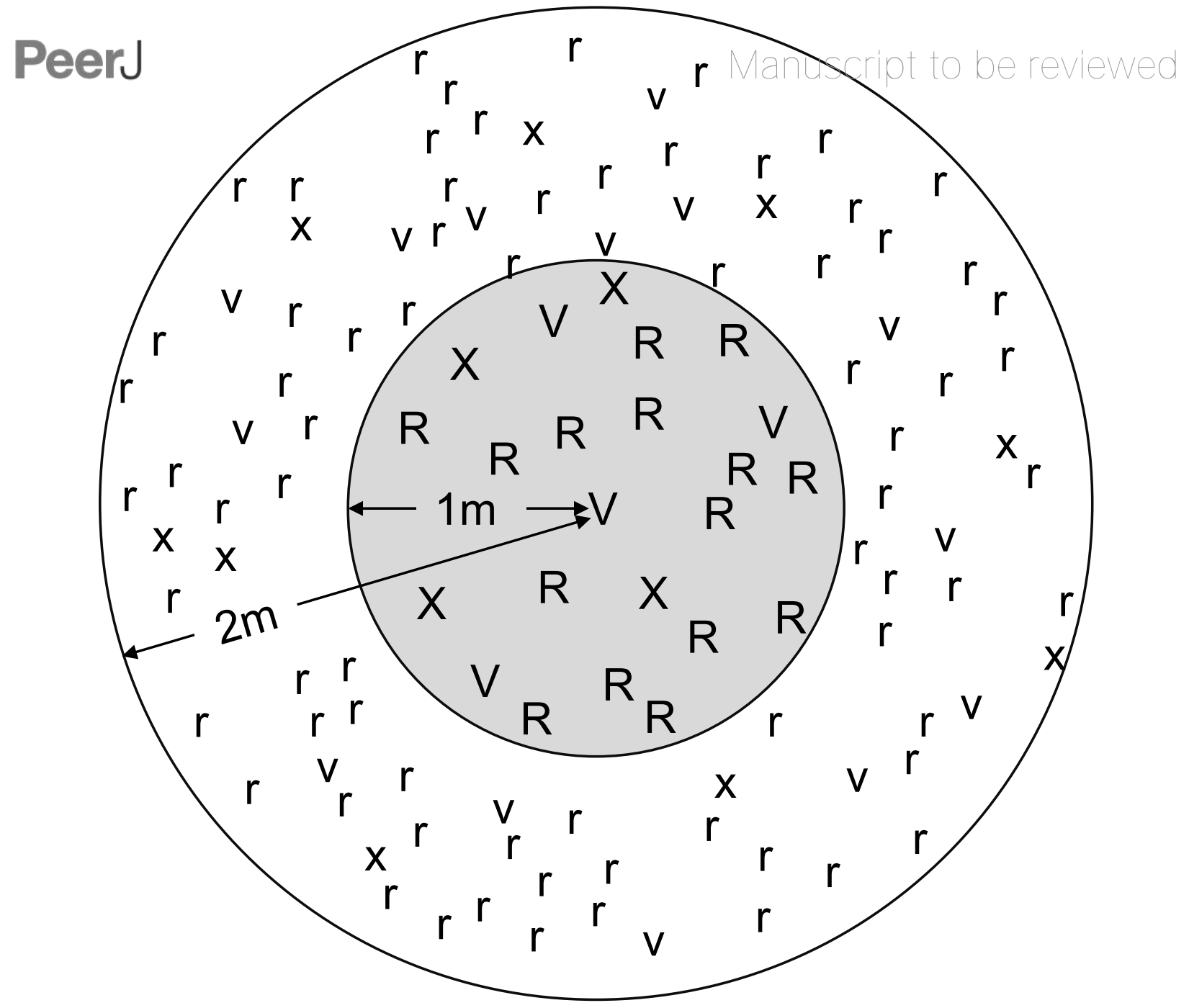




\section{Figure 2}

Seed bank densities in different (a) habitat types and (b) soil depth layers, and (c) percentage viability of these seeds of Virgilia divaricata, Acacia mearnsii, and $A$. melanoxylon

Means \pm SE of untransformed data are shown for seed bank densities and percentage viability. Seeds were sampled under the canopy of mature trees (with stem diameter of 20$50 \mathrm{~cm}$ ) of three species ( $\mathrm{N}=10$ trees per species) in natural stands along the southern Cape coast of South Africa. 

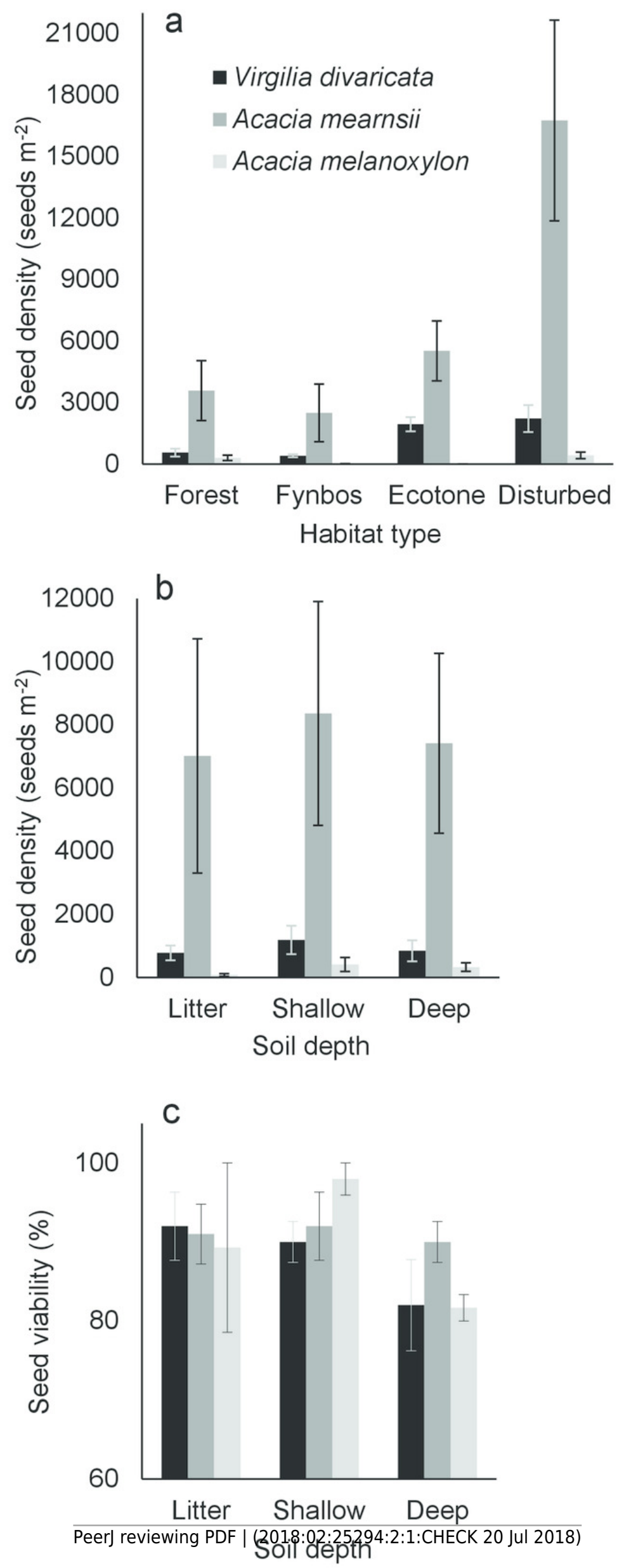


\section{Figure 3}

Root and shoot dry masses, and root:shoot ratios of Virgilia divaricata ( $\mathrm{N}=96)$ and Acacia mearnsii $(\mathrm{N}=110)$ seedlings harvested three months after the planting of seeds.

Means \pm SE of untransformed values are shown for all measures. The species differed significantly from each other $(p<0.001)$ in terms of all three measures.

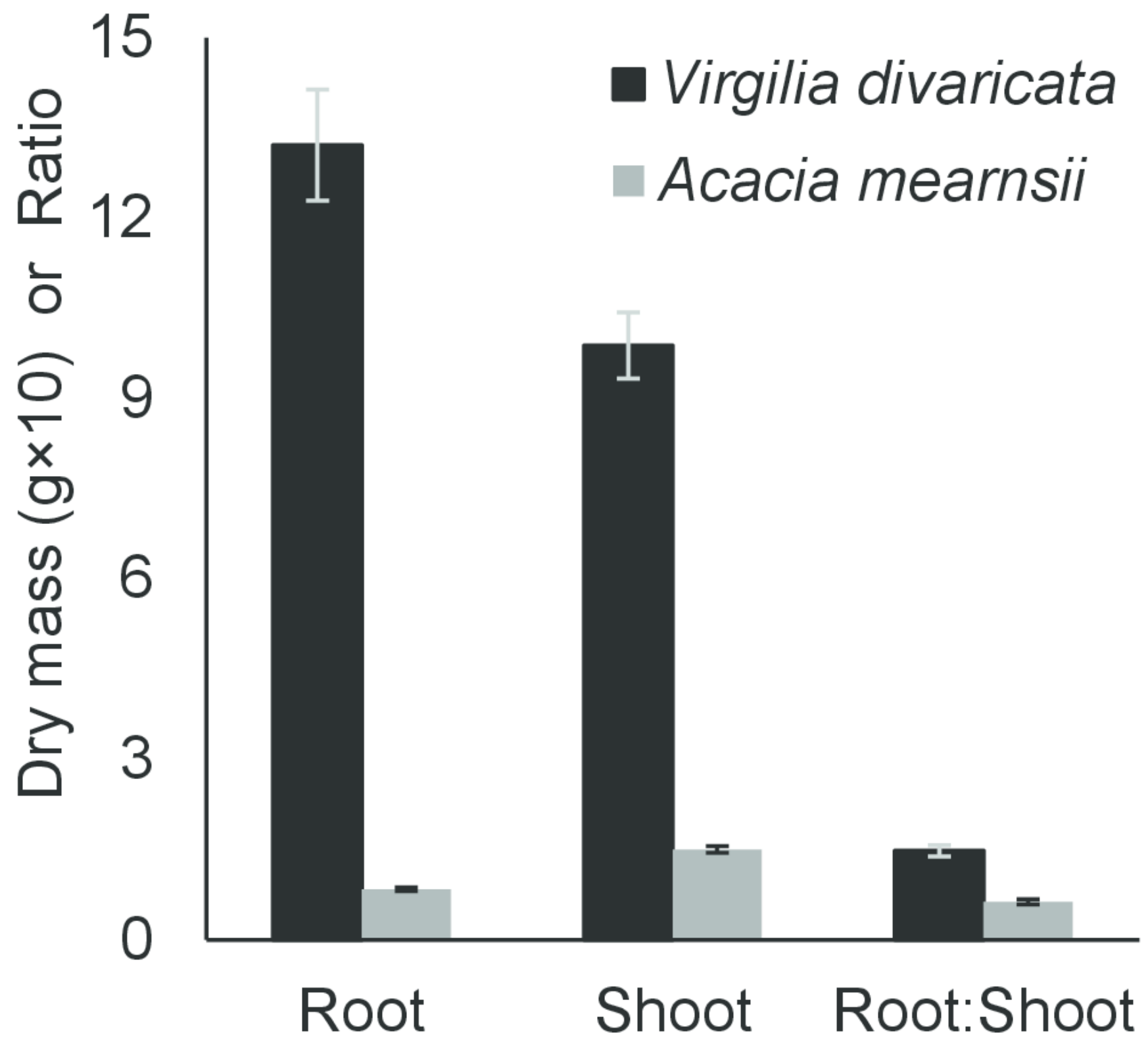




\section{Figure 4}

Relationships between growth increment and initial size for seedlings and saplings of $V$. divaricata, A. mearnsii, and A. melanoxylon.

The different panels show seedling growth in height for (a) V. divaricata and (b) A. mearnsii; sapling growth in ( $c, d, e)$ height, $(f, g, h)$ groundline diameter (GLD), and (i, j, k) biomass index (BI) for V. divaricata, A. mearnsii and A. melanoxylon, respectively. Saplings (of 0.2 $8.0 \mathrm{~cm}$ groundline diameter) regenerated naturally where pine plantations were clear-felled 3 - 5 years prior to the study.
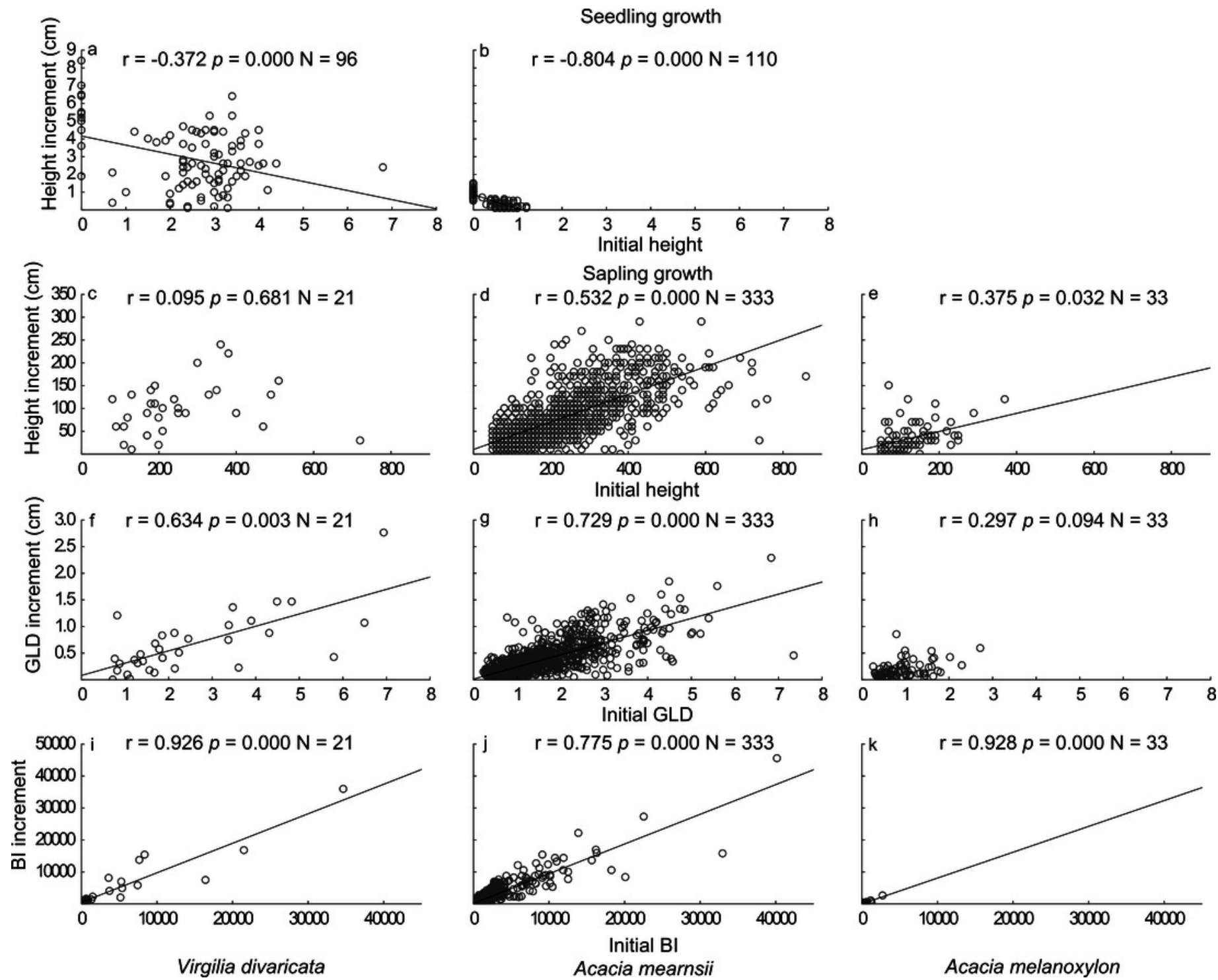


\section{Table $\mathbf{1}$ (on next page)}

Mixed-model results of the effects of species, soil depth and habitat type on seed bank densities of Virgilia divaricata, Acacia mearnsii and $A$. melanoxylon.

Results of mixed-model analysis of variance to assess the effects of species and soil depth (as fixed effects), habitat type (as random effect), and second-order interactions (as fixed effects) on seed bank density, expressed as $\log \left(\right.$ seeds $\mathrm{m}^{-2}+1$ ). See text for details of categories within factors. 


\begin{tabular}{lccccc}
\hline Effect & df Effect & MS Effect & df Error & F & $p$ \\
\hline Species & 2 & 23.08 & 6.29 & 17.65 & 0.002 \\
Depth & 2 & 1.32 & 66.00 & 2.8817 .56 & 0.063 \\
Habitat & 3 & 8.08 & 66.00 & 0.76 & $<0.001$ \\
Species*Depth & 4 & 0.35 & 66.00 & 4.18 & 0.551 \\
Species*Habitat & 6 & 1.92 & 66.00 & 0.78 & 0.001 \\
Depth*Habitat & 6 & 0.36 & 66.00 & & 0.584 \\
\hline
\end{tabular}

1 


\section{Table 2 (on next page)}

Seed bank densities (seeds $\mathrm{m}^{-2}$ ) and viability (\%) of Virgilia divaricata, Acacia mearnsii, and $A$. melanoxylon recorded in this study and compared to seed bank densities reported in literature.

a Pieterse (1997); ${ }^{\mathrm{b}}$ Garner (2007); ${ }^{\mathrm{c}}$ Milton and Hall (1981); ${ }^{\mathrm{d}}$ Donald (1959) cited in Milton and

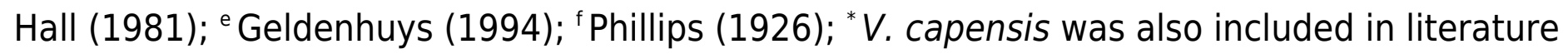
searches as $V$. divaricata and $V$. oroboides were both referred to as $V$. capensis prior to taxonomic revision; ${ }^{* *} T o$ enable comparison with the literature, our seed counts were converted to seed numbers $\mathrm{m}^{-2}$. 


\begin{tabular}{lcccc}
\cline { 2 - 4 } Species & \multicolumn{2}{c}{ Seed bank density $\left(\mathrm{seeds} \mathrm{m}^{-2}\right)^{* *}$} & \multicolumn{2}{c}{ Seed viability (\%) } \\
& $\begin{array}{c}\text { Current study } \\
\text { mean (range) }\end{array}$ & Literature & Current study & Literature \\
\hline V. divaricata & $938(170-3406)$ & $15-685^{\mathrm{e}} ; 500-2000^{\mathrm{f}}$ & 88 & $90-99^{\mathrm{f}}$ \\
A. mearnsii & $7596(57-35060)$ & $5314^{\mathrm{a}} ; 38340^{\mathrm{c}}$ & 91 & $92^{\mathrm{b}}$ \\
A. melanoxylon & $274(0-1262)$ & $2860-94420^{\mathrm{d}}$ & 87 & $70^{\mathrm{c}} ; 90^{\mathrm{d}}$ \\
\hline
\end{tabular}

